\author{
Contato \\ Departamento de Economia - FEA/USP \\ Av. Professor Luciano Gualberto, 908 \\ 05508-010 - São Paulo - São Paulo \\ rcolistete@usp.br
}

\section{INICIATIVAS LOCAIS E MOBILIZAÇÃO POR ESCOLAS PRIMÁRIAS EM SÃO PAULO, 1830-1889*}

\author{
Renato Perim Colistete**
}

Universidade de São Paulo

São Paulo - São Paulo - Brasil

\title{
Resumo
}

O artigo mostra como pais e moradores organizaram-se em diversas regiões da província de São Paulo e submeteram petições aos seus representantes locais e ao legislativo provincial requerendo a instalação de escolas, desde as primeiras décadas do Império. As câmaras municipais e, na década de 1880, os conselhos de instrução reforçaram a demanda local por ensino primário. Em meio a condições particularmente desfavoráveis, as evidências de mobilização por escolas públicas ganham um significado especial e levantam dúvidas sobre as perspectivas que, nos séculos XIX e $\mathrm{XX}$, rejeitaram a viabilidade do autogoverno local devido à alegada incapacidade do "povo" de intervir na esfera pública de forma consequente.

\section{Palavras-chave}

Educação primária - municípios - São Paulo - escola pública.

* Este artigo beneficiou-se de inúmeras conversas com Bruno Witzel, Gustavo Barros, Maria Lucia Lamounier, Pedro Funari, Pedro Garcia Duarte e William Summerhill, a quem agradeço nesta oportunidade. Agradeço também aos valiosos comentários e sugestões dos pareceristas da Revista de História.

** Doutor em História Moderna pela Universidade de Oxford. Professor livre-docente de História Econômica da Faculdade deEconomia, Administração eCiências Contábeis da Universidade de São Paulo. 


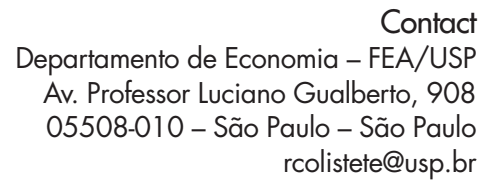

Contact

Departamento de Economia - FEA/USP

Av. Professor Luciano Gualberto, 908

05508-010 - São Paulo - São Paulo rcolistete@usp.br

\section{LOCAL INITIATIVES}

AND MOBILIZATION

FOR PRIMARY

SCHOOLS IN SÃO

PAULO, 1830-1889

\section{Renato Perim Colistete}

Universidade de São Paulo

São Paulo - São Paulo - Brazil

\begin{abstract}
One of the most common explanations for the historical deficiencies of public primary education in Brazil has been the alleged indifference of families that lacked resources to send their children to private schools. This article addresses such an issue in a period covering most of the Empire, when the conditions for access to primary schools were especially unfavourable. Poverty, isolation, illiteracy, political centralization and bureaucracy inhibited local initiatives and created few incentives, if any, for families to get involved in primary schools. The article shows, however, that parents and residents organized themselves across the province of São Paulo and submitted petitions to their local representatives and the provincial assembly requiring the installation of schools, since the first decades of the Empire. Town councils and, in the 1880s, education councils strengthened local demand for primary education. Under particularly adverse conditions, the evidence of mobilization for public schools gains a special significance and raises doubts about the views that, in the nineteenth and twentieth centuries, rejected the viability of local self-government due to the alleged inability of the "people" to intervene in the public sphere consistently.
\end{abstract}

\title{
Keywords
}

Primary education - municipalities - São Paulo - public school. 
Este artigo trata de um aspecto pouco visível e conhecido da história da educação primária em São Paulo e no Brasil como um todo: como as populações nas localidades enfrentaram a escassez e as deficiências das escolas públicas? O artigo circunscreve a tentativa de resposta a essa questão ao Império, embora a pergunta seja igualmente relevante para o período republicano. Em geral, presume-se que pais, moradores e câmaras municipais adotaram uma atitude indiferente em relação às escolas primárias públicas, resignando-se a acolher as decisões dos governos para a abertura ou não de vagas nas diferentes partes da província de São Paulo. Da mesma forma, as propostas e iniciativas de abertura de escolas, quando notadas, tendem a ser vistas frequentemente como produto exclusivo da ação ilustrada de governantes e membros da elite sensíveis à exclusão da maioria da população do ensino elementar. ${ }^{1}$

Este artigo, porém, demonstra que, assim como publicistas e políticos atuantes em todos os partidos do Império - defenderam em várias ocasiões o ideal de universalização do ensino primário, pais e moradores também pressionaram as câmaras locais e o próprio legislativo provincial pela abertura de escolas nas áreas rurais e urbanas de São Paulo. Essas reivindicações ocorreram tanto em núcleos urbanos e sedes de municípios quanto em bairros rurais e distantes, assim como incluíram pedidos de vagas para as crianças do sexo feminino que mais sofriam com a exclusão educacional. Mais ainda, famílias pobres de brasileiros e imigrantes participaram dessas iniciativas, muitas vezes contando com pais - às vezes em maioria - que não haviam aprendido a ler e escrever. ${ }^{2}$ Acompanhando essa tendência, em várias ocasiões as câmaras municipais pressionaram os governos da província por escolas que atendessem a população local.

\footnotetext{
1 Apenas para mencionar duas obras influentes: NAGLE, Jorge. Educação e sociedade na Primeira República. São Paulo: Editora Pedagógica e Universitária, 1974, cap. 3-4; MARCÍLIO, Maria Luiza. História da escola em São Paulo e no Brasil. São Paulo: Imprensa Oficial do Estado de São Paulo e Instituto Fernand Braudel, 2005, p. 127-44.

2 Sobre a demanda por ensino em bairros de São Paulo na segunda metade do século XX, ver CAMPOS, Maria M. Malta. Escola e participação popular: a luta por educação elementar em dois bairros de São Paulo. Tese de doutorado em Ciências Sociais, Faculdade de Filosofia, Letras e Ciências Humanas, Universidade de São Paulo, 1982; SPOSITO, Marília Pontes. O povo vai à escola: $a$ luta popular pela expansão do ensino público em São Paulo. São Paulo: Loyola, 1984. Ana Luiza Costa utiliza petições de famílias por vagas e melhorias de escolas públicas no Rio de Janeiro na década de 1870: COSTA, Ana Luiza Jesus da. O educar-se das classes populares oitocentistas no Rio de Janeiro entre a escolarização e a experiência. Tese de doutorado em Educação, Faculdade de Educação, Universidade de São Paulo, 2012.
} 
Além das reivindicações pela abertura de aulas públicas mantidas pelo governo provincial, houve também iniciativas por parte de entidades - como lojas maçônicas, sociedades de instrução popular e gabinetes de leitura - que criaram escolas noturnas gratuitas em várias cidades da província de São Paulo. ${ }^{3}$ Da mesma forma, imigrantes europeus que chegaram à província a partir da década de 1840 criaram escolas étnicas em diversas comunidades urbanas e rurais - tal como fizeram alemães e suíços em Rio Claro, Limeira e Indaiatuba. ${ }^{4}$ Em comum, essas iniciativas buscavam contornar a carência de estabelecimentos oficiais de ensino por meio da auto-organização de membros das comunidades, abrangendo tanto representantes das classes médias locais quanto os próprios beneficiários diretos das escolas, como no caso dos imigrantes. Embora essas ações sejam importantes para entender a demanda por instrução primária, este artigo concentra-se em reivindicações especificamente voltadas a atrair investimentos públicos, isto é, recursos fiscais da província para o ensino primário das localidades.

O regime constitucional que se consolidou com o Ato Adicional de 1834 transferiu para as províncias a responsabilidade pela instrução primária no

\footnotetext{
3 Ver HILSDORF, Maria Lucia Spedo. Francisco Rangel Pestana: o educador esquecido. Brasília: Instituto Nacional de Estudos e Pesquisas Educacionais, 1998, p. 58; FERREIRA, Salete Beatriz Braga Xavier. A expansão escolar campineira e a grande lavoura no fim do Império (1860-1889). Dissertação de mestrado em Educação, Faculdade de Educação, Universidade Estadual de Campinas, 1982, p. 178-206; MORAES, Carmen S. Vidigal. O ideário republicano e a educação: o ensino em Campinas no final do século XIX. Revista da Faculdade de Educação, vol. 11, nº 1-2, São Paulo, 1985 , p. 120-23; RIBEIRO, Luaê Carregari Carneiro. Uma América em São Paulo: a maçonaria e o Partido Republicano Paulista (1868-1889). Dissertação de mestrado em História, Faculdade de Filosofia, Letras e Ciências Humanas, Universidade de São Paulo, 2011, p. 51-65. Um breve levantamento compreendendo apenas vagas noturnas gratuitas indica o surgimento de 24 escolas em 18 cidades da província de São Paulo entre 1869 e 1879 (os dados podem ser requisitados ao autor).

${ }^{4}$ GRININGER, Valdemar. Imigração suíça em São Paulo: a história da colônia Helvetia. Dissertação de mestrado em História, Instituto de Filosofia e Ciências Humanas, Universidade Estadual de Campinas, 1991; BEZERRA, Maria Cristina S. Imigração, educação e religião: um estudo histórico-sociológico do bairro dos Pires de Limeira, uma comunidade rural de maioria teuto-brasileira. Dissertação de mestrado em Educação, Faculdade de Educação, Universidade Estadual de Campinas, 2001 e Idem. Educação étnica: a pluralidade das propostas educacionais de origem germânica no Estado de São Paulo. Tese de doutorado em Educação, Faculdade de Educação, Universidade Estadual de Campinas, 2007; ALVES, Silvane R. L. A instrução pública em Indaiatuba: 1854-1930. Contribuição para a história da educação brasileira. Dissertação de mestrado em Educação, Faculdade de Educação, Universidade Estadual de Campinas, 2007; SOUZA, Bruno Gabriel Wietzel de. The combined effect of institutions and human capital for economic development: a case study of German immigration to São Paulo, Brazil, 1840-1920. Master dissertation in Development Economics, Chair of Development Economics, Georg-August-Universität Göttingen, 2014, cap. 3-4 e apêndice, tabela A1.
} 
Brasil, algo já estabelecido pela lei geral de 15 de outubro de 1827.5 Segundo a lei de 1828 que regulou o regime das municipalidades, caberia às câmaras a fiscalização das aulas e dos professores, sendo mesmo o exercício dessa função fiscalizadora sujeito à jurisdição do legislativo e do executivo provinciais. ${ }^{6}$ A centralização do ensino elementar estendia-se à contratação dos professores e ao financiamento das escolas. Em São Paulo, as câmaras municipais adaptaram-se a esse regime de maneira ambígua durante o Império: se não tomaram iniciativas para instalar e financiar escolas elementares próprias, por outro lado, elas exerceram pressão sobre a assembleia legislativa para abertura de aulas primárias nos municípios. Essa atitude das câmaras decorria em grande medida da distribuição constitucional das competências acerca do ensino elementar e das múltiplas obrigações que recaíam sobre as municipalidades na condução da polícia, da justiça e da economia locais. ${ }^{7}$

Foi nesse contexto que a negociação entre administrações municipais e provinciais tornou-se parte das regras do jogo que se definiram nas décadas iniciais do Império. Obviamente, a barganha entre os governos subnacionais não era simétrica, como ficou claro desde o regime de tutela consagrado pelo Ato Adicional de 1834: a iniciativa das câmaras era filtrada pelos canais do governo e do legislativo provinciais, que detinham o poder de aprovar ou não seus pleitos. Esse era um mecanismo vital para o exercício do poder político e econômico nas províncias de todo o país, inclusive por meio das nomeações de professores e da abertura de escolas em trocas clientelistas.

A outra dimensão das iniciativas locais diz respeito às demandas por escolas primárias públicas feitas pelos próprios pais e moradores de vilas e povoados. Essas iniciativas são ainda de mais difícil identificação, pois tomaram a forma de pedidos informais ou - o que é objeto deste artigo - petições encaminhadas às câmaras municipais ou diretamente às comissões de cons-

\footnotetext{
5 BRASIL. Lei n ${ }^{\circ} 16$ de 12 de agosto de 1834, art. 10 e 11. Collecção das leis do Imperio do Brazil - 1834, parte I. Rio de Janeiro: Typographia Nacional, 1866; BRASIL. Lei de 15 de outubro de 1827. Collecção das leis do Imperio do Brazil - 1827, parte I. Rio de Janeiro: Typographia Nacional, 1878; LEAL, Aurelino. Historia constitucional do Brazil. Rio de Janeiro: Imprensa Nacional, 1915, p. 117-18, 174-75; JAMES, Herman G. The constitutional system of Brazil. Washington: Carnegie Institution, 1923, p. 4-7. 6 BRASIL. Lei de $1^{\circ}$ de outubro de 1828. Collecção das leis do Imperio do Brazil - 1828, parte I. Rio de Janeiro: Typographia Nacional, 1878; LAXE, João Baptista Cortines. Regimento das camaras municipaes. $2^{\text {a }}$ edição. Rio de Janeiro: B. L. Garnier, 1885, p. 198-99.

7 MAIA, João de Azevedo Carneiro. O municipio. Estudos sobre administração local. Rio de Janeiro: Typ. de Leuzinger $\mathcal{E}$ Filhos, 1883, p. 190-92, 230-33; LEAL, Victor Nunes. Coronelismo, enxada e voto. O município e o regime representativo no Brasil. $2^{\text {a }}$ edição. São Paulo: Alfa-Omega, 1979 [1949].
} 
tituição, justiça e instrução pública da assembleia legislativa, sendo somente depois aprovadas ou não pelo legislativo.

A baixa visibilidade das ações das câmaras municipais e de pais e moradores tende a ocultar o papel da iniciativa local dentro de um sistema centralizado, em que a província ocupou o papel preponderante frente às municipalidades. As câmaras e os moradores de áreas urbanas e rurais agiam na maior parte das vezes dentro dos marcos dessas instituições centralizadas, dificilmente ultrapassando-as ou contestando-as. Do mesmo modo, a tutela exercida pelo governo e pela assembleia provincial sobre as municipalidades tolhia e frustrava as iniciativas locais. Não obstante, representantes locais, pais e moradores mobilizaram-se em diversas ocasiões e regiões da província de São Paulo pela abertura de escolas primárias públicas.

As implicações das iniciativas diretas da população em favor da educação primária vão além da esfera educacional propriamente dita. Os princípios que restringiram a autonomia das instituições locais no regime constitucional do Império, e que persistiram praticamente intactos na República, foram inspirados em grande medida em uma concepção negativa da capacidade do "povo" de intervir na esfera pública de forma consequente. Nessa perspectiva, as instituições democráticas do autogoverno (self-government) local seriam inadequadas e impraticáveis no Brasil. ${ }^{8}$ As reivindicações locais por escolas durante o Império, no entanto, indicam a preocupação de pessoas comuns e seu envolvimento com temas - no caso, a formação educacional de seus filhos - que tradicionalmente são considerados de interesse exclusivo de membros ilustrados das elites econômicas e políticas. A participação direta nas decisões

\footnotetext{
${ }^{8}$ Essa concepção remonta às disputas nas décadas de 1830 e 1840 em torno das reformas liberais e do "regresso". Os relatórios e obras produzidos por Paulino José Soares de Sousa, o visconde do Uruguai, estão entre os trabalhos mais elaborados e representativos dessa perspectiva. Ver por exemplo: BRASIL. Ministério da Justiça. Relatorio da Repartição dos Negocios da Justiça apresentado á Assembléa Geral Legislativa na sessão ordinaria de 1841, pelo respectivo Ministro e Secretario de Estado, Paulino José Soares de Sousa. Rio de Janeiro: Typographia Nacional, 1841, p. 19-20; Visconde do Uruguay. Ensaio sobre o direito administrativo. Rio de Janeiro: Typographia Nacional, 1862, p. 201. Tal perspectiva tornou-se dominante na historiografia do século XX, a começar pelos trabalhos influentes de Oliveira Viana: VIANA, Francisco José de Oliveira. Pequenos estudos de psicologia social. $3^{a}$ edição. São Paulo: Cia. Editora Nacional, 1942 [1921] e Idem. Instituições políticas brasileiras. Brasília: Senado Federal, 1999 [1949]. A principal crítica contemporânea a essa concepção é a de BASTOS, Aureliano Cândido Tavares. A provincia. Estudo sobre a descentralisação no Brazil. Rio de Janeiro: B. L. Garnier, 1870, p. 31. Para uma revisão crítica dessas interpretações a partir do estudo das reformas das instituições judiciárias brasileiras no século XIX, ver FLORY, Thomas. Judge and jury in imperial Brazil, 1808-1871. Social control and political stability in the new state. Austin: University of Texas Press, 1981.
} 
de políticas importantes como as relativas à educação elementar não foi descartada pelos beneficiários diretos das escolas públicas, apesar da centralização das decisões e do financiamento do ensino primário durante o Império.

Essas questões são tratadas em detalhe a seguir. A primeira seção apresenta evidências da atuação das câmaras municipais em favor da criação de escolas em várias localidades de São Paulo. Também são abordados nesta parte os pedidos encaminhados pelos conselhos de instrução criados pela Reforma da Instrução Pública de 1887, a última aprovada na província de São Paulo antes da República. A segunda seção reconstitui as petições submetidas por pais e moradores à assembleia legislativa e aos presidentes da província de São Paulo. Na análise são destacados os argumentos expostos nas petições e, no caso dos pais e moradores, as suas características em termos de alfabetização e nacionalidade. A última seção resume as conclusões principais.

\section{A atuação das câmaras municipais}

Já nos primeiros anos da assembleia legislativa em São Paulo, algumas câmaras municipais representaram ao governo provincial pedindo a criação de escolas de primeiras letras. Em geral, os vereadores fundamentavam seus pedidos relatando a ausência de escolas e as dificuldades enfrentadas pelas crianças de famílias pobres. Um exemplo foi a decisão da câmara de São Sebastião, no litoral norte, de solicitar em 1838 a criação de uma escola de primeiras letras no bairro São Francisco, onde dizia haver 150 famílias com 700 pessoas livres, das quais apenas duas famílias conseguiam matricular seus filhos em aulas públicas mais distantes. Segundo a representação, a criação da escola era uma medida de "urgente necessidade" para aquele bairro, cujos habitantes reclamavam constantemente "de sua indigência". Na mesma época, a câmara de Atibaia, na região central da província, havia apresentado um pleito semelhante em favor da freguesia de Santo Antônio da Cachoeira (atual Piracaia). De acordo com o texto enviado ao legislativo provincial, o aprendizado dos princípios elementares de leitura e escrita era "de tão reconhecida utilidade, que ninguém há mais de duvidar, que é só deles que se pode provir a qualquer País a sua ilustração e engrandecimento". No entanto, segundo os representantes municipais, o ensino elementar

\footnotetext{
9 São Sebastião, Criação de escola, 1838, Fundo Assembleia Legislativa Provincial - Império [citado a seguir como Fundo Impériol, Acervo Histórico da Assembleia Legislativa de São Paulo [a seguir Acervo Histórico Alesp], caixa 428, documento [doc. nas referências a seguir] IP38.13.3.
} 
naquela freguesia só era "suportado (...) por aqueles da gente abastada, enquanto a gente pobre e aquela mesma de mediana fortuna se viam no desalento, e na suma mágoa de não poderem com tais dotes enriquecer seus filhos" com as primeiras letras. ${ }^{10}$

Houve casos em que as câmaras pediam escolas especificamente para as meninas, como ocorreu já em 1835 em Jacareí, no Vale do Paraíba. Segundo os vereadores, não havia em todo o município escola do sexo feminino, razão pela qual apelavam ao "patriotismo" dos membros da assembleia legislativa para que as meninas sem recursos pudessem aprender a ler e escrever. ${ }^{11}$ Também na mesma época e região a câmara de Lorena reivindicou uma escola para meninas, dizendo esperar que os deputados tomassem na devida consideração "este objeto tão reclamado pelos Pais de Família."12 No ano seguinte, os representantes de Franca do Imperador, no extremo oeste da província, relatavam que a aula para meninas antes existente deixou de ser oferecida devido à mudança do antigo professor, razão pela qual solicitavam a contratação de uma professora já conhecida na vila. ${ }^{13}$ Da mesma forma, a câmara de Bananal, no Vale do Paraíba, afirmava em 1839 que, estando os meninos já atendidos por escolas no município, era preciso então instalar uma aula para meninas para que "o sexo feminino não fique privado deste alimento moral".14 A vila de Mogi-Mirim, no oeste, fez um pedido similar ao legislativo provincial. A comissão encarregada da assembleia legislativa não foi, porém, sensível aos dois últimos pedidos, dizendo a respeito das escolas para meninas que "a necessidade delas é certamente muito menor do que a de muitas outras coisas que nos faltam", não recomendando sequer que a matéria fosse apreciada pelos deputados. ${ }^{15}$

As localidades que já dispunham de aulas públicas, por sua vez, enfrentavam dificuldades para manter os professores com os baixos vencimentos que recebiam do governo provincial. O exemplo de Batatais, no oeste da província, é ilustrativo. O professor local pediu demissão "alegando que não poderia tratar de sua família com tal gratificação". A câmara tomou a iniciativa de procurar outra pessoa que aceitasse o encargo com a gratificação

\footnotetext{
${ }^{10}$ Atibaia, Criação de escola, 1838. Fundo Império, Acervo Histórico Alesp, caixa 428, doc. IP38.17.2.

${ }^{11}$ Jacareí, Criação de escola, 1836. Fundo Império, Acervo Histórico Alesp, caixa 428, doc. IP36.4.2.

${ }^{12}$ Lorena, Criação de escola, 1836. Fundo Império, Acervo Histórico Alesp, caixa 428, doc. IP36.6.3.

${ }^{13}$ Franca, Criação de escola, 1836. Fundo Império, Acervo Histórico Alesp, caixa 428, doc. IP36.3.2.

${ }^{14}$ Bananal, Criação de escola, 1839. Fundo Império, Acervo Histórico Alesp, caixa 428, doc. IP39.1.3.

${ }^{15}$ Vários municípios, Parecer da Comissão de Estatística, Fazenda e Instrução Pública, 1839. Fundo Império, Acervo Histórico Alesp, caixa, 428, doc. IP39.11.1.
} 
estabelecida, "porém nem pelo dobro achou quem servisse". O secretário da câmara de Batatais continuava "por condescendência" a servir no papel de professor e pedia-se providências da assembleia legislativa. ${ }^{16}$

O relato das dificuldades e necessidades da instrução primária nos municípios ganhou novo impulso com a aprovação pelo presidente Rafael Tobias de Aguiar, em 1841, de uma lei que determinou que as câmaras municipais enviassem anualmente, um mês antes da abertura da assembleia provincial, um relatório descrevendo "as necessidades de seus municípios e as providências que entendam mais adequadas para prover a respeito". As câmaras deveriam informar o estado de estradas, instrução primária, prisões, igrejas matrizes e o atendimento dos órfãos pobres. ${ }^{17}$ Esses relatórios continuaram sendo produzidos e enviados ao governo provincial durante o Império, chegando ao período republicano sob formas modificadas, ao lado de petições e reivindicações específicas submetidas ao governo provincial pelas câmaras ou diretamente por moradores. A maior parte dos relatórios enfatizava as condições de estradas, logradouros, chafarizes, igrejas, cemitérios e as obras requeridas, com a situação das escolas recebendo em geral menor destaque, o que refletia possivelmente o baixo envolvimento direto das localidades com o ensino das crianças. Mas em algumas oportunidades, os relatórios apresentavam diagnósticos dos problemas enfrentados pela instrução primária nos municípios e propunham soluções.

Um exemplo desses relatórios é o apresentado em 1843 pelo município de Itu, um dos mais antigos e prósperos da província. O documento informa que 59 crianças estavam então matriculadas na escola de primeiras letras do sexo masculino, mas o professor queixava-se de tantas ausências que às vezes não tinha trabalho. Além disso, nela "tudo falta", diz o documento: "lápis, bons traslados, tinteiros, impressos ou compêndios", tendo os pais de adquirir o material, não obstante serem muito pobres. ${ }^{18}$ Outro município antigo, Jundiaí, relatou na mesma época que possuía apenas uma aula pública com 22 alunos matriculados, "que pouco aproveitamento aparentam". Localizada nesse município, a freguesia de Belém do Jundiaí (atual Itatiba) reivindicava a criação da primeira escola de primeiras letras, que a câmara dizia haver

\footnotetext{
${ }^{16}$ Batatais, Falta de instrução primária, 1840. Fundo Império, Acervo Histórico Alesp, caixa 429, doc. IP40.3.1.

17 São Paulo, Lei n ${ }^{\circ} 2$ de 21 de janeiro de 1841.

${ }^{18}$ Itu, Necessidades do município, 1843. Fundo Império, Acervo Histórico Alesp, caixa 251, doc. CR 43.22.3.
} 
pleiteado em várias ocasiões. ${ }^{19}$ Por sua vez, os representantes de Porto Feliz, na antiga região do açúcar, afirmavam em 1850 haver somente uma aula pública do sexo feminino, com 12 alunas, em funcionamento no município, uma vez que a do sexo masculino "está há muito vaga". Existiam, no entanto, quatro aulas particulares com 80 alunos matriculados na localidade. ${ }^{20}$ As dificuldades apareciam também em municípios relativamente novos, como o de Batatais, criado em 1839. Dois anos depois, esse município não possuía escolas primárias públicas ou particulares, "com que muito sofre o público". ${ }^{21}$

Mais incisiva foi a descrição da câmara de Bananal em 1848, localizada em uma região - Vale do Paraíba - em rápido crescimento devido à produção e exportação de café. O relatório afirma que a "instrução pública nesta vila é absolutamente nula", havendo uma cadeira para o sexo masculino e outra para o sexo feminino que "não se acham providas, e nem será possível que a sejam, enquanto forem tão miseráveis os vencimentos que estão marcados para os Mestres, vencimentos absolutamente insuficientes para subsistência", pois os preços na vila eram elevados. Não avançariam o governo e a assembleia legislativa, continuava a câmara, "com seus regulamentos e sábias disposições" enquanto não se puder dar "aos mestres os meios de decente subsistência". O resultado era que "só frequentam escolas particulares aqueles meninos cujos pais estão em circunstância de pagar o ensino, ficando a classe numerosa dos pobres inteiramente privada da instrução primária indispensável". A câmara pedia então que enquanto não fosse possível "uma medida geral em favor dos Professores da província", pelo menos se ajustasse suficientemente "o ordenado para as Cadeiras desta Vila". ${ }^{22}$

Em outro relatório, mais de uma década depois, a situação descrita em Bananal era parecida, apenas sendo feita uma distinção entre a sede da vila e a área rural: a câmara denunciava "o desgraçado estado da instrução pública deste Termo", embora dissesse que o cenário era melhor na sede do município. Mas os representantes enfatizavam a mesma distinção de classe social que foi notada anos antes: "[a] classe pobre acha-se inibida de parti-

\footnotetext{
19 Jundiaí, Necessidades do município, 1843. Fundo Império, Acervo Histórico Alesp, caixa 251, doc. CR 43.245.

${ }^{20}$ Porto Feliz, Necessidades do município, 1850. Fundo Império, Acervo Histórico Alesp, caixa 254, doc. CR 50.31.

${ }^{21}$ Batatais, Necessidades do município, 1841. Fundo Império, Acervo Histórico Alesp, caixa 249, doc. CR 41.2.1.

${ }^{22}$ Bananal, Necessidades do município, 1848. Fundo Império, Acervo Histórico Alesp, caixa 253, doc. CR 48.1.1.
} 
cipar da primeira instrução que foi concedida em todos os lugares pela falta de professores. Hoje, neste município, só aqueles que são ricos é que podem dar instrução aos seus filhos porque dispõem de meios pecuniários para este fim", levando-os com facilidade para "a Corte ou capital da província". O mesmo "não acontece com os pobres pais de família que não são favorecidos pela fortuna". A câmara pedia ao governo provincial a provisão das cadeiras com aumento dos ordenados dos professores, "visto que os aluguéis das casas e os gêneros alimentícios estão aqui por preços fabulosos", sem o que não seria possível achar "pessoas habilitadas que se dediquem ao ensino público". ${ }^{23}$

Na maioria das vezes, as avaliações não eram tão críticas como as feitas pela câmara de Bananal, predominando nos relatórios dos municípios referências breves sobre o número de matriculados ou simplesmente a omissão do tema da instrução primária. Havia também os casos em que a situação do ensino era considerada boa pelas câmaras, como aconteceu com Taubaté em 1843, que relatou que o estado da instrução primária era "vantajoso" no município, com 68 meninas e 102 meninos matriculados nas aulas públicas. ${ }^{24}$ Já em Tatuí, existia em 1845 uma aula pública para 45 alunos (nenhuma vaga para meninas), com a câmara assegurando que os matriculados tinham "grande aproveitamento". ${ }^{25}$ Duas décadas depois, a câmara de vila Bela da Princesa (Ilhabela) relatava que o estado da instrução pública na vila era "assaz lisonjeiro e satisfatório", com quatro aulas de primeiras letras para o sexo masculino e três para o sexo feminino, "todas frequentadas por grande número de alunos e alunas."26 De qualquer forma, uma avaliação tão positiva quanto a da câmara de Bela da Princesa foi mais exceção do que regra na época.

Os requerimentos e pedidos avulsos enviados à assembleia legislativa continuaram fazendo parte da rotina das municipalidades ao lado dos relatórios oficiais previstos pela lei de 1841. As câmaras enfatizaram não apenas a exclusão das crianças de famílias pobres, mas enviaram também pedidos específicos de aulas para meninas ou para ambos os sexos. Em 1845, por exemplo, os representantes de vila Bela da Princesa observavam que sendo

\footnotetext{
${ }^{25}$ Bananal, Necessidades do município, 1860. Fundo Império, Acervo Histórico Alesp, caixa 254, doc. CR 60.1.2.

${ }^{24}$ Taubaté, Necessidades do município, 1843. Fundo Império, Acervo Histórico Alesp, caixa 252, doc. CR 4344.2

${ }^{25}$ Tatuí, Necessidades do município, 1846. Fundo Império, Acervo Histórico Alesp, caixa ESP-113, doc. IO 46.104.

${ }^{26}$ Bela da Princesa, Necessidades do município, 1867. Fundo Império, Acervo Histórico Alesp, caixa 255, doc. CR 67.2.1
} 
"uma necessidade quase indispensável (...) a instrução de ambos os sexos, a Câmara Municipal desta Vila julga de seu dever representar a V.S a o atraso que sente nosso município com a falta de cadeira de instrução primária para o sexo feminino" - cuja criação, diziam os vereadores, "será de grande vantagem para o melhoramento da civilização" do município. ${ }^{27}$ A mesma importância à educação das meninas foi dada pela câmara da vila de São Roque, na região de Sorocaba, em um pedido similar no mesmo ano: "Esta câmara julga desnecessário demonstrar as vantagens resultantes desta medida porque não desconheceis a transcendente utilidade dela, e só lembra que há nesta Vila um grande número de meninas que deixa de receber estes princípios de educação tão salutar quão necessária por falta de meios". ${ }^{28}$ Em 1846, os vereadores da vila de Limeira adotavam o mesmo tom em sua representação por uma cadeira para o sexo feminino, baseada em sua "plena convicção de que a instrução pública de ambos os sexos sem dúvida deve ser o principal interesse Provincial pelo bem que disso pode resultar à massa geral dos Habitantes". ${ }^{29}$ É provável que representações como essas e as outras citadas anteriormente tenham contribuído diretamente para o rápido crescimento das matrículas do sexo feminino desde os anos 1840, reduzindo a distância em relação ao número de matrículas do sexo masculino, como constatado pelas estatísticas oficiais. ${ }^{30}$

Em várias oportunidades, as câmaras municipais testemunharam a defasagem entre a oferta de escolas e o rápido crescimento econômico das localidades, com o consequente aumento da população em suas sedes e bairros. Em 1843, por exemplo, a câmara de Jacareí alertava para “a urgente necessidade que há de criar-se uma cadeira de primeiras letras na Freguesia de Santa Branca" (atual Santa Branca), "tendo em vista o grande número de meninos que já ali habitam alguns deles de boas famílias, porém pobres, e por isso inabilitadas de procurarem fora da dita Freguesia a instrução primária". ${ }^{31}$ Dois anos depois, a vila de Atibaia comunicava ao legislativo provincial "uma das mais urgentes necessidades que sofre uma parte dela, a

\footnotetext{
${ }^{27}$ Bela da Princesa, Criação de escola, 1845. Fundo Império, Acervo Histórico Alesp, caixa 429, doc. IP 45.1.2.

${ }^{28}$ São Roque, Criação de escola, 1845. Fundo Império, Acervo Histórico Alesp, caixa 547, doc. IP 45.5.1.

${ }^{29}$ Limeira, Criação de escola, 1846. Fundo Império, Acervo Histórico Alesp, caixa ESP-173, doc. IP 46.7.1.

${ }^{30}$ COLISTETE, Renato Perim. O atraso em meio à riqueza: uma história econômica da educação primária em São Paulo, 1835 a 1920. Tese de livre-docência, Faculdade de Economia, Administração e Contabilidade, Universidade de São Paulo, 2016.

31 Jacareí, Criação de escola, 1844. Fundo Império, Acervo Histórico Alesp, caixa 547, doc. PR 44.84.4.
} 
Freguesia de Santo Antônio da Cachoeira" (Piracaia). Segundo os vereadores, embora se destacasse pela "qualidade da terra em que está situada, e mesmo pela sua extensão", contendo nela "pequena riqueza", a freguesia "achavase em estado sumamente lastimável por falta de instrução primária", o que afetava inclusive sua representação política na câmara municipal dado o pequeno número de cidadãos que sabiam ler e escrever. ${ }^{32}$

O problema da insuficiência de vagas em meio ao rápido crescimento populacional continuou sendo registrado pelas municipalidades nos anos seguintes. Em 1860, a câmara de Santos reivindicou a criação de mais duas cadeiras para ambos os sexos, pois as escolas existentes possuíam mais de 70 alunos cada, impedindo que o professor pudesse ensinar adequadamente. ${ }^{33}$ Situação idêntica ocorria em Itu, que pleiteou alguns anos depois mais duas escolas de ambos os sexos para as crianças da localidade. ${ }^{34} \mathrm{Na}$ mesma época, os representantes de Taubaté diziam que a freguesia de Santa Cruz do Paiolinho (atual município de Redenção da Serra) possuía "grande número de habitantes e grande parte del[a] consta de lavradores chefes de famílias numerosas, e que não podem dar a seus filhos o ensino elementar da língua materna, já por falta de recursos e por morarem muito distantes da cidade". Uma vez que "a instrução pública é um dos ramos dos negócios públicos que devem merecer todo o cuidado", os vereadores pediam que se instalasse a primeira escola primária para meninos na freguesia, até então desprovida de instrução pública. ${ }^{35}$ Em 1876, a câmara da vila de Cananeia, no litoral sul, pedia "mais duas cadeiras de instrução primária de ambos os sexos visto que as duas cadeiras existentes não podem acumular tão avultado número de alunos", o que estaria causando "grande demora no adiantamento" dos que estavam matriculados. ${ }^{36}$

Os mesmos problemas de ausência ou insuficiência de escolas foram registrados pelas câmaras das novas áreas da expansão cafeeira. Em Campinas, por exemplo, os representantes do município solicitaram em 1868 a instalação de uma escola de meninos no "importante bairro de Santa Cruz" (Cam-

\footnotetext{
${ }^{32}$ Atibaia, Criação de escola, Atibaia, 1846. Fundo Império, Acervo Histórico Alesp, caixa 430, doc. IP 46.2.1.

33 Santos, Criação de escola, 1860. Fundo Império, Acervo Histórico Alesp, caixa ESP-176, doc. IP 60.3.1.

${ }^{34}$ Itu, Criação de escola, 1864. Fundo Império, Acervo Histórico Alesp, caixa 433, doc. IP 64.2.3.

${ }^{35}$ Taubaté, Criação de escola, 1865. Fundo Império, Acervo Histórico Alesp, caixa ESP-177, doc. IP 65.10.2.

${ }^{36}$ Várias cidades (Cananeia), Criação de escola, 1876. Fundo Império, Acervo Histórico Alesp, caixa ESP-178, doc. IP 76.9.5.
} 
buí), enquanto em Brotas, também no oeste cafeeiro, os vereadores afirmavam que o restabelecimento de uma cadeira do sexo feminino que havia sido suprimida alguns anos antes era "uma das mais urgentes necessidades da localidade". ${ }^{37}$ Em 1876, a câmara de São Simão, no então oeste novo da província, pedia uma escola para meninas, uma vez que no município havia "uma grande porção da mocidade desse sexo" que deixava "de se instruir nas primeiras letras pela falta de meios para pagar a uma professora que [lhes desse] a necessária instrução". ${ }^{38}$ Em Santa Bárbara (atual Santa Bárbara do Oeste), na região de Campinas, a câmara fez um pedido diferente: "uma subvenção anual de um conto e duzentos mil-réis para a escola americana", que funcionava em um templo protestante no bairro do Campo, situado a uma légua da sede da vila. A escola já possuía então "20 alunos americanos". Outras famílias, tanto de imigrantes quanto brasileiras, poderiam passar a frequentar as aulas primárias caso se aprovasse a dotação regular de recursos, argumentavam os vereadores do município. ${ }^{39}$

As câmaras municipais prosseguiram submetendo representações por mais escolas que descreviam as condições de ensino nas vilas, bairros e áreas rurais durante a década de 1880. Em geral, os pedidos feitos à assembleia legislativa relatavam a insuficiência de vagas frente ao grande número de crianças que estavam fora da escola. A câmara de Amparo, por exemplo, na região da Mogiana, enviou em 1885 requisição de uma nova escola masculina para a sede do município, pois cada uma das duas já existentes era "frequentada por mais de sessenta alunos que não podem receber a instrução conveniente apesar da boa vontade dos respectivos professores", o que era agravado pelo fato de que "ambos os professores ensinam em suas casas por falta de edifícios apropriados para escolas". No ano seguinte, a mesma câmara reivindicava uma cadeira adicional para o bairro dos Pereiras, visto que este era "assaz populoso e distante da Cidade de modo que os seus habitantes lutam com dificuldade para dar instrução a seus filhos" ${ }^{40}$ A câmara

${ }^{37}$ Campinas, Criação de escola, 1868. Fundo Império, Acervo Histórico Alesp, caixa 433, doc. IP 68.1.1; Brotas, Criação de escola, 1870. Fundo Império, Acervo Histórico Alesp, caixa 434, doc. IP 70.1.3.

${ }^{38}$ São Simão, Criação de escola, 1876. Fundo Império, Acervo Histórico Alesp, caixa 435, doc. IP 76.11.2.

39 Santa Bárbara, Subvenção para escola, 1877. Fundo Império, Acervo Histórico Alesp, caixa 192, doc. CF 77.75.1.

40 Amparo, Criação de escola primária, 1885. Fundo Império, Acervo Histórico Alesp, caixa 383, doc. CJ 85.2.2; Criação de escola primária, 1886. Fundo Império, Acervo Histórico Alesp, caixa 438, doc. IP 86.1.2. 
de Jambeiro, no Vale do Paraíba, solicitou em 1883 uma cadeira adicional do sexo masculino no município, "visto ser grande o número de indivíduos por matricular na que aqui há". ${ }^{41}$ Já na vila da Penha do Rio do Peixe (Itapira), na Mogiana, a câmara defendia em 1886 a "urgente necessidade" de uma segunda cadeira para o sexo feminino a ser "regida exclusivamente por professora formada pela Escola Normal", diante do "progresso que tem feito este Município pelo aumento de sua população, atingindo quase a dez mil almas". ${ }^{42}$

É provável que muitas das representações das câmaras municipais em favor de escolas tivessem origem em pedidos submetidos aos seus representantes por aqueles que eram os beneficiários diretos da instrução pública, isto é, os pais e moradores dos bairros e vilas. Décadas atrás, este havia sido o caso, por exemplo, da câmara de Lorena em 1836, que apenas serviu de intermediária para a reivindicação dos moradores da freguesia de Silveiras de criação de uma escola de primeiras letras para as meninas da localidade. ${ }^{43}$ Em 1886, a câmara de Bragança, na região central, dizia atender "à justa aspiração dos habitantes do bairro Mãe dos Homens" para a "necessidade de criar-se uma escola pública de instrução primária para o sexo masculino".44 Na mesma época, a câmara de Taubaté requisitava uma escola também para meninos no bairro de Ribeirão das Almas, a fim de "atender as justas reclamações dos respectivos habitantes, que pedem instrução para o avultado número de meninos que ali existe."45

Além de câmaras, os conselhos municipais criados pela Reforma da Instrução Pública de 1887 tornaram-se outro meio pelo qual foram conduzidas as reivindicações por escolas em vilas e bairros. ${ }^{46}$ A lei $n^{0} 81$ de 6 de abril de 1887 estabeleceu a instalação de conselhos de instrução nos municípios, formados por dois membros eleitos da câmara e um representante nomeado pelo governo provincial. A limitação do conselho a membros da câmara municipal e outro indicado pelo governo foi um revés em relação ao pro-

\footnotetext{
${ }^{41}$ Jambeiro, Criação de escola primária, 1883. Fundo Império, Acervo Histórico Alesp, caixa 437, doc. IP 83.7.1.

${ }^{42}$ Penha do Rio do Peixe, Criação de escola primária, 1886. Fundo Império, Acervo Histórico Alesp, caixa 438, doc. IP 86.13.1.

${ }^{43}$ Lorena, Criação de escola, 1836. Fundo Império, Acervo Histórico Alesp, caixa 428, doc. IP 36.6.3.

${ }^{44}$ Bragança, Criação de escola primária, 1886. Fundo Império, Acervo Histórico Alesp, caixa 438, doc. IP 86.4.1

${ }^{45}$ Taubaté, Criação de escola primária, 1887. Fundo Império, Acervo Histórico Alesp, caixa 441, doc. IP 87.54.1.

${ }^{46}$ São Paulo, Lei ${ }^{\circ} 81$ de 6 de abril de 1887. A lei foi implementada pelo Regulamento de 22 de agosto de 1887. Ver COLISTETE, Renato Perim. $O$ atraso em meio à riqueza, op. cit., cap. 9.
} 
jeto original aprovado pela assembleia legislativa, que previa que os cargos dos conselhos de instrução fossem preenchidos apenas por membros eleitos diretamente pelos pais e professores das localidades. ${ }^{47}$ Apesar disso, há evidências de que os conselhos de instrução, na forma limitada aprovada pela Reforma de 1887, reforçaram a mobilização de pais e responsáveis em seus pedidos por mais escolas elementares. Foi o que ocorreu com o conselho municipal de Tatuí, na região de Sorocaba, que, diante da "necessidade da difusão das luzes" no município, deliberou em fevereiro de 1889 propor à assembleia legislativa a criação de uma escola no bairro da Aleluia, que atenderia de 30 a 40 alunos lá residentes e que permaneciam sem instrução. ${ }^{48}$ Em Santos, o conselho de instrução submeteu, em 1888, um pedido de duas novas escolas para meninos e outras duas para meninas na cidade, tendo em vista a insuficiência das vagas existentes, além de mais uma cadeira mista no bairro de Vila Mathias, que ainda não possuía aula primária. ${ }^{49}$ No ano seguinte, o conselho municipal de Mogi das Cruzes, na região do Vale do Paraíba, fez uma representação para abertura de cadeiras para 63 meninos que residiam em dois bairros do município. ${ }^{50}$

Possivelmente vários pedidos dos conselhos, da mesma forma que aqueles submetidos pelas câmaras, resultassem da interferência direta de pais e moradores. Em março de 1889, um pedido de Mogi-Mirim, na Mogiana, relatou que os habitantes de um bairro da cidade "reclamam a criação de uma cadeira do sexo feminino", diante do que o conselho de instrução se dizia "convencido de que essa reclamação traduz uma necessidade", enviando a reivindicação à assembleia legislativa. O pedido trazia uma lista com o nome de 30 meninas de 5 a 15 anos que deveriam frequentar a nova escola. ${ }^{51} \mathrm{Em}$ janeiro do mesmo ano, os moradores do bairro de Jabaquara, na vila Bela da Princesa, enviaram ao conselho de instrução municipal um abaixo-assinado dizendo ser de "muita necessidade a criação de uma cadeira para o sexo feminino", por residirem distante de outros bairros e não haver comunicação

${ }_{47}$ COLISTETE, Renato Perim. O atraso em meio à riqueza, op. cit., cap. 9.

${ }^{48}$ Tatuí, Criação de escola primária, 1888. Fundo Império, Acervo Histórico Alesp, caixa 445, doc. IP 89.63.3.

${ }^{49}$ Santos, Criação de escola primária, 1888. Fundo Império, Acervo Histórico Alesp, caixa 441, doc. IP 88.9.1.

${ }^{50}$ Mogi das Cruzes, Criação de escola primária, 1889. Fundo Império, Acervo Histórico Alesp, caixa 444, doc. IP 89.24.1.

${ }^{51}$ Mogi Mirim, Criação de escola primária, 1889. Fundo Império, Acervo Histórico Alesp, caixa 444, doc. IP 89.25.2. 
por terra, apenas pelo mar. Um total de 32 meninas seria beneficiado pela medida. O documento foi assinado por 20 pais, sendo nove analfabetos. Ao dirigir-se à assembleia legislativa, o conselho municipal considerou "justa e atendível a pretensão dos reclamantes". ${ }^{52}$

Além de pressionar câmaras e conselhos de instrução locais, pais e moradores também tomaram iniciativas diretas, em diferentes partes de São Paulo, para reivindicar escolas ao legislativo e ao executivo provinciais, como veremos a seguir.

\section{Pais e moradores reivindicam escolas}

Embora a tentativa de identificar a demanda local por escolas esbarre no problema de difícil solução da escassez de relatos e outras fontes escritas sobre o cotidiano de vilas e bairros, é possível reconstituir pelo menos fragmentos das atitudes de pais e moradores por meio das petições enviadas à assembleia legislativa reivindicando escolas para as crianças. Essas representações geralmente incluíam um preâmbulo em que os signatários descreviam a situação vivida pelas famílias e justificavam a importância da criação de vagas para a instrução primária pública. Com o passar do tempo, as petições passaram a incluir dados dos alunos que estavam fora das escolas, com seus nomes, idades, sexo e filiação. Além disso, na maioria das vezes, as representações ao legislativo eram assinadas pelos moradores que reivindicavam escolas. Essas informações serão utilizadas a seguir para apresentar um panorama de quais podem ter sido as características gerais da demanda por instrução primária pelas famílias nas sedes de vilas e bairros urbanos e rurais da província de São Paulo até o final da década de 1880.

Frequentemente, as petições destacavam as distâncias em que as famílias residiam das escolas existentes e a falta de recursos dos pais para arcarem com as despesas da educação dos filhos. Os bairros e áreas rurais afastados das sedes das vilas costumavam sofrer especialmente com esses problemas. É ilustrativo o caso relatado por uma representação enviada em 1840 por 22 moradores da freguesia de São João de Rio Claro, então parte do município de Constituição (Piracicaba), reivindicando a indicação de "um Mestre de instrução primária que pela muita pobreza de seus habitantes muitos não podem concorrer a frequentar Aulas particulares, muito menos em outros

\footnotetext{
${ }^{52}$ Bela da Princesa, Criação de escola primária, 1889. Fundo Império, Acervo Histórico Alesp, caixa 443, doc. IP 89.3.1.
} 
distritos". ${ }^{53}$ Igualmente, em 1845, os moradores da freguesia de Nossa Senhora do Patrocínio de Água Choca (atual município de Monte Mor), em Itu, diziam que, sendo a maioria formada por lavradores, "poucos podem pagar um Mestre que ensine as primeiras letras e muito menos mandar seus filhos à escola da cidade". ${ }^{4}$ Vinte e seis moradores do bairro Enseada em São Sebastião, no litoral norte, submeteram em 1859 uma petição à assembleia legislativa requerendo uma escola para meninos. O bairro ficava a uma légua (6,6 km) da vila, o que tornava impossível, segundo os moradores, que as crianças frequentassem a escola existente, não só pela distância a ser percorrida, mas pelo fato dos pais não poderem arcar com casas alugadas na sede ou com criados para cuidar de seus filhos, "visto serem parte dos signatários pessoas pobres". ${ }^{55}$ Anos depois, na mesma região do litoral, os habitantes de um bairro de Caraguatatuba também pediam uma aula pública, visto que a única existente na vila era demasiadamente distante para as crianças. ${ }^{56}$ Motivos idênticos justificaram em 1873 a petição dos moradores da ilha dos Porcos (ilha Anchieta) em Ubatuba, que reivindicaram uma escola para o sexo feminino: a distância de três léguas e meia da sede da vila e a carência de recursos faziam com que mais de 40 meninas ficassem sem instrução. ${ }^{57}$

As dificuldades de acesso à escola não eram limitadas às regiões rurais e distantes. Moradores da capital e empregados em atividades urbanas enfrentaram problemas semelhantes e também se organizaram para pedir escolas em São Paulo. Por exemplo, os residentes do bairro do Pari, na capital, reivindicaram em 1873 uma escola para ambos os sexos, uma vez que os pais da localidade sofriam por "não poder mandar seus filhos às (...) escolas por ficarem muito longe"..$^{8}$ As novas estações ferroviárias que vinham sendo criadas na época também deram origem a novos núcleos populacionais que careciam de escolas: em 1874, vinte e dois moradores da freguesia de São Bernardo (atual São Bernardo do Campo) representaram ao legislativo provincial dizendo não poder "deixar de lembrar (...) a grande utilidade que

\footnotetext{
53 São João do Rio Claro, Criação de escola, 1840. Fundo Império, Acervo Histórico Alesp, caixa 429, doc. IP 40.8.1.

${ }^{54}$ Itu, Criação de escola, 1845. Fundo Império, Acervo Histórico Alesp, caixa 429, doc. IP 45.3.3.

55 São Sebastião, Criação de escola, 1859. Fundo Império, Acervo Histórico Alesp, caixa 432, doc. IP 59.19.1.

${ }^{56}$ Caraguatatuba, Criação de escola, 1863. Fundo Império, Acervo Histórico Alesp, caixa ESP-177, doc. IP 631.1.

${ }^{57}$ Ubatuba, Criação de escola, 1873. Fundo Império, Acervo Histórico Alesp, caixa 435, doc. IP 73.16.1.

${ }^{58}$ Capital, Criação de escola, 1873. Fundo Império, Acervo Histórico Alesp, caixa 434, doc. IP 73.8.1.
} 
resultará da criação das duas cadeiras da Estação da estrada de ferro em São Bernardo", pois no seu entorno existiam "para mais de 60 meninos de ambos os sexos que por falta de recursos não podem frequentar as escolas da Freguesia pela distância de suas residências". ${ }^{59}$ A mesma dificuldade era vivida pelos moradores do Alto da Serra, na estrada da capital para Santos. Segundo eles, "grande número de meninos de ambos os sexos (...) estão aí sem poderem receber a instrução, pois seus pais, em sua maior parte, trabalhadores e empregados na linha da Estrada de Ferro, não podem de modo algum fazer os gastos da instrução" ou conduzir seus filhos a lugares distantes com escolas. Por esse motivo, os 26 moradores que assinavam a representação solicitavam uma escola para meninos e outra para meninas na localidade. ${ }^{60}$

Ao lado dos relatos da distância das escolas e da pobreza da população que necessitava do ensino primário, pais e moradores costumavam justificar seus pedidos com o que viam ser as consequências negativas da ausência de instrução para as crianças. Os moradores citados acima da freguesia de Nossa Senhora do Patrocínio de Água Choca, em Itu, que reivindicaram em 1845 uma escola de primeiras letras, lembraram em sua representação ao legislativo que a "Constituição do Império no $\$ 32$ do art. 179 garante gratuitamente a todos os cidadãos a instrução pública". Também notaram que "o imposto sobre aguardente que no princípio teve a denominação de subsídio literário, e que tinha essa particular aplicação, é pago pelo povo desta Freguesia (...) sem que o aproveite". Além de tudo, havia motivos mais amplos, segundo os moradores, para a assembleia legislativa atender a sua reivindicação: "é muito óbvio o interesse do Estado: ter homens instruídos, e ninguém o pode ser sem os primeiros elementos".61

Argumentos parecidos foram utilizados em outras oportunidades e épocas. Quando 16 pais do bairro de Caraguatatuba, fato já mencionado anteriormente, reivindicaram uma escola para meninas, eles lamentavam que, caso não fossem atendidos, "continuarão a ver os seus filhos como que no estado primitivo". ${ }^{2}$ Para 32 moradores de Porto Feliz, na região central, a instalação "de uma segunda cadeira de primeiras letras", onde "os menos favorecidos pela fortuna" poderiam "instruir seus filhos", seria justificada porque

\footnotetext{
59 Capital, Criação de escola, 1874. Fundo Império, Acervo Histórico Alesp, caixa 435, doc. IP 74.4.1.

${ }^{60}$ Capital, Criação de escola, 1875. Fundo Império, Acervo Histórico Alesp, caixa 435, doc. IP 75.3.2.

${ }^{61}$ Itu, Criação de escola, 1845. Fundo Império, Acervo Histórico Alesp, caixa 429, doc. IP 45.3.3.

${ }^{62}$ Caraguatatuba, Criação de escola, 1863. Fundo Império, Acervo Histórico Alesp, caixa ESP-177, doc. IP 631.1.
} 
"da instrução do povo depende toda a felicidade social". ${ }^{63}$ Em Botucatu, na Alta Sorocabana, os moradores da capela de São Manuel (hoje município de São Manuel) pediam aos deputados, em 1874, que lançassem "suas benéficas vistas a este cantão da província" e se dignassem "a criar uma fonte de luzes para os habitantes desta Capela". ${ }^{64}$ Vinte e seis pais do bairro do Senhor Bom Jesus da Cana Verde em Campinas, "não podendo por deficiência de recursos fazê-los [seus filhos] frequentar aulas nas Cidades", pediam em 1876 "a urgente instalação" de uma aula primária para meninos, pois estes "jazem em uma completa e absoluta ignorância". ${ }^{65}$ À idêntica conclusão chegaram os moradores do bairro Quilombo, em Lorena, ao reivindicarem uma escola para ambos os sexos: "não menos de 100 meninos entre uns e outros em ponto de aprenderem a ler (...) vegetam em completa ignorância". ${ }^{66}$

Na última década do Império, as petições organizadas por moradores reivindicando a instalação de escolas em bairros e áreas rurais parecem ter se tornado mais frequentes. Os moradores do povoado de Lavrinhas, estação da ferrovia D. Pedro II e distrito do então município de Pinheiros (atual Lavrinhas), no Vale do Paraíba, reivindicaram em 1886 a criação de uma cadeira para crianças do sexo feminino, por contar a localidade com "avultado número de alunas, que ressentem a falta de instrução". "É sempre difícil", continuavam os autores, "dar-se uma educação mediana às meninas, porque este lugar dista da Vila de Pinheiros seis quilômetros, tornando-se penosa a frequência nas escolas daquele lugar". Os signatários eram todos alfabetizados e incluíam proprietários, negociantes, empregados públicos e funcionários da ferrovia - somando 46 nomes ao todo. ${ }^{67}$ A criação de novos núcleos populacionais em torno das estações ferroviárias pelo interior da província trazia agora uma demanda adicional por novas escolas primárias, e não apenas para o sexo masculino.

Nas petições, havia também a participação de indivíduos com relação apenas indireta com moradores e seus filhos sem acesso à instrução primária. Em 1884, uma representação com 100 assinaturas em Piracicaba pleiteou

\footnotetext{
${ }^{63}$ Porto Feliz, Criação de escola, 1868. Fundo Império, Acervo Histórico Alesp, caixa 433, doc. IP 68.2.1.

${ }^{64}$ Botucatu, Criação de escola, 1874. Fundo Império, Acervo Histórico Alesp, caixa ESP-178, doc. IP 74.1.1.

${ }^{65}$ Várias cidades (Campinas), Criação de escola, 1876. Fundo Império, Acervo Histórico Alesp, caixa ESP-178, doc. IP 76.9.2.

${ }^{66}$ Lorena, Criação de escola, 1878. Fundo Império, Acervo Histórico Alesp, caixa ESP-179, doc. IP 78.4.1.

${ }^{67}$ Pinheiros, Criação de escola primária, 1886. Fundo Império, Acervo Histórico Alesp, caixa 438, doc. IP 86.16 .1
} 
a instalação de uma escola primária para meninos no bairro da Rua do Porto, reforçando o pedido com o argumento de que o lugar era "povoado em sua totalidade por pessoas desfavorecidas da fortuna que pela distância das escolas naturalmente bem poucos pais mandam seus filhos a instruírem-se". Entre os que subscreveram o pedido havia negociantes, comerciantes, farmacêuticos, advogados, médicos, agricultores, professores, empregados do comércio, jornalista e delegado de polícia, provavelmente a maioria deles não residente no bairro. Nenhum dos que assinaram o documento era analfabeto. ${ }^{68}$

Um fato que chama a atenção por todo o período é que, entre os que subscreviam as petições, encontravam-se pais que não sabiam ler e escrever. É o que se deduz da presença de assinaturas redigidas por terceiros em nome do responsável - por exemplo, utilizando-se o termo "a rogo de" fulano. No caso de uma representação da localidade de Porto de Cubatão, em Santos, no ano de 1849, dos 31 pais que pediram uma escola de primeiras letras para "mais de 20 crianças ali abandonadas sem recurso", cerca de 15 deles (48\%) não foram capazes de assinar o nome. ${ }^{69}$ Os moradores da povoação de M'Boi (atual Embu das Artes), na região da capital, relatavam em 1859 a existência de "trinta e tantos meninos, filhos de pais indigentes" para justificar a necessidade de uma escola primária pública, "que espalhe as primeiras instruções sobre a infância desvalida". Trinta e três assinaram a petição, dos quais 12 deles (36\%) eram analfabetos. ${ }^{70}$ Esses percentuais poderiam ser ainda maiores, como aconteceu dois anos depois com a representação dos habitantes da freguesia do Paiolinho (Redenção da Serra), em Taubaté, que afirmaram ser de "urgente necessidade" a criação de uma cadeira de primeiras letras para meninos: dos 98 signatários do documento, nada menos do que 57\% deles não sabiam escrever. ${ }^{71}$

Como era de se esperar, apareciam também petições em que todos os seus autores eram alfabetizados, principalmente quando a demanda por escola sensibilizava, além dos diretamente beneficiados, outros membros da comunidade local, tais como comerciantes, juízes e profissionais liberais.

\footnotetext{
${ }^{68}$ Piracicaba, Criação de escola primária, 1884. Fundo Império, Acervo Histórico Alesp, caixa 437, doc. IP 84.4.2.

${ }^{69}$ Santos, Criação de escola, 1849. Fundo Império, Acervo Histórico Alesp, caixa 430, doc. IP 49.3.2.

${ }^{70}$ Santo Amaro, Criação de escola, 1859. Fundo Império, Acervo Histórico Alesp, caixa 432, doc. IP 59.5.1. O povoado de M'Boi era parte da freguesia de Itapecerica (hoje Itapecerica da Serra), pertencente ao então município de Santo Amaro.

${ }^{71}$ Taubaté, Criação de escola, 1861. Fundo Império, Acervo Histórico Alesp, caixa ESP-177, doc. IP 61.10.1.
} 
Esse foi o caso da petição de moradores de Piracicaba em 1884, citado acima. Mas casos similares ocorreram em décadas anteriores, como o pedido de uma cadeira de ensino elementar submetido pelos residentes da freguesia de Nossa Senhora do Socorro, na vila de Nova Bragança (Bragança Paulista) em 1843. Entre os 27 nomes listados, todos eram alfabetizados, com boa parte dos signatários declarando ocupações públicas e empresariais: juiz de paz, subdelegado, sargento da Guarda Nacional, negociantes, proprietários e fiscal, entre outros. ${ }^{72}$ Vários anos depois, moradores da vila de São Simão, na Mogiana, que se diziam "testemunhas legítimas das necessidades" do local, afirmavam "que a que mais urge principalmente e que por isso reclama pronto cuidado, é a de uma Aula Pública para o sexo feminino para esta mesma Vila". Os 13 autores eram alfabetizados e possuíam ocupações como delegado de polícia, juiz municipal, juiz de paz e tabelião. ${ }^{73}$

De qualquer maneira, a presença de pais e moradores sem instrução continuou ao longo dos anos sendo comum nas representações enviadas ao legislativo provincial, às vezes com a maioria de signatários revelando-se incapaz de ler e escrever. Na petição dos moradores do bairro do Pari em 1873, na capital, já citada anteriormente, apenas um dos nove signatários era alfabetizado. Uma situação semelhante ocorreu em um povoado do município de Belém do Jundiaí (Itatiba) em 1877 na região central. Na lista de pais e seus respectivos filhos que não recebiam instrução, 15 (75\%) de um total de 20 adultos que subscreveram o pedido não eram alfabetizados. Segundo esse levantamento, havia 32 crianças que se beneficiariam da instalação de uma escola primária pública. O que é digno de nota é que duas dessas crianças eram filhos de escravos: Gabriel Conceição, de 6 anos, livre, "filho da escrava Fabiana"; e Benedito de Conceição, 6 anos, livre e filho da "escrava Anna". As duas mães aparentemente não sabiam escrever e seus senhores assinaram por elas. Um terceiro menino, Benedito Forro, 12 anos, filho de Maria Nuncia, provavelmente ex-escrava, teve seu nome redigido por uma terceira pessoa. ${ }^{74}$ Essas informações sugerem que, pelo menos em alguns casos, a opinião de que a instrução elementar era importante foi compar-

\footnotetext{
${ }^{72}$ Nossa Senhora do Socorro (Nova Bragança), Criação de escola, 1843. Fundo Império, Acervo Histórico Alesp, caixa 429, doc. IP 43.4.1.

73 São Simão, Criação de escola, 1872. Fundo Império, Acervo Histórico Alesp, caixa 434, doc. IP 72.4.

${ }^{74}$ Várias cidades (Belém do Jundiaí), Criação de escola, 1877. Fundo Império, Acervo Histórico Alesp, caixa 435, doc. IP 77.11.4.
} 
tilhada por famílias pobres e, inclusive, por mães submetidas ao regime de cativeiro e libertas.

Vale observar que o acesso à educação primária por parte de escravos no Brasil é um assunto tão pouco conhecido quanto as iniciativas de famílias pobres por escolas. ${ }^{75}$ Uma das raras informações oficiais disponíveis foi compilada pelo recenseamento demográfico de 1872 que, porém, não registrou qualquer criança escrava em idade escolar recebendo algum tipo de instrução primária em São Paulo. Apenas 0,07\% da população cativa eram alfabetizados, comparado a 20,7\% da população livre. ${ }^{76}$ Além da visão geral dos escravistas de que a educação dos cativos seria irrelevante ou provavelmente até perigosa, contribuía para o analfabetismo praticamente absoluto entre os escravos as restrições para que as crianças escravas frequentassem as escolas oficiais - embora a primeira proibição legal em São Paulo tenha vindo somente com o Regulamento da Instrução Pública de $1869 .{ }^{77}$ Mesmo assim, alguns poucos escravos ou filhos de escravos chegaram a receber instrução fora dos estabelecimentos oficiais, em escolas noturnas subvencionadas pelas câmaras ou mantidas por gabinetes de leitura, lojas maçônicas e sociedades de instrução popular surgidas durante as décadas de 1870 e 1880 nos municípios de maior expressão em São Paulo. Como já foi mencionado, essas iniciativas são um importante exemplo da demanda por instrução primária, mas fogem do escopo deste artigo. Após a Lei do Ventre Livre (1871), os filhos de famílias escravas também passaram a formar o contingente de crianças que poderiam ter acesso à escola primária, ao lado das pertencentes às famílias pobres livres, como no caso citado da petição em Belém do Jundiaí.

\footnotetext{
${ }^{75}$ Um dos poucos trabalhos mais detalhados sobre a instrução de escravos e libertos em São Paulo (capital) é o de BARROS, Surya A. P. de. "Negrinhos que por ahí andão": a escolarização da população negra em São Paulo (1870-1920). Dissertação de mestrado em Educação, Faculdade de Educação, Universidade de São Paulo, 2005. A respeito de outras províncias, ver SCHUELER, Alessandra F. Martinez de. Crianças e escolas na passagem do Império para a República. Revista Brasileira de História, São Paulo, vol. 19, nº 37, 1999, p. 59-84; FONSECA, Marcos Vinícius. Pretos, pardos, crioulos e cabras nas escolas mineiras do século XIX. Tese de doutorado em Educação, Faculdade de Educação, Universidade de São Paulo, 2007; CRUZ, Marileia dos Santos. A educação dos negros na sociedade escravista do Maranhão provincial. Outros Tempos, São Luís, vol. 6, nº 8, 2009 , p. 110-29; SILVA, Noemi Santos da. O "batismo da instrução": projetos e práticas de instrução formal de escravos, libertos e ingênuos no Paraná provincial. Dissertação de mestrado em História, Setor de Ciências Humanas, Letras e Artes, Universidade Federal do Paraná, 2014.

${ }^{76}$ Calculado de BRASIL. Recenseamento da população do Império do Brasil de 1872, vol. I. Rio de Janeiro: Typ. de Leuzinger e Filhos, 1876, 428.

${ }^{77}$ BARROS, Surya de. "Negrinhos que por ahí andão", op. cit., cap. 2, seções 2.2 e 2.3. O Regulamento de 1869 colocou em prática a Lei no 54 de 15 de abril de 1868.
} 
Pais sem alfabetização aparecem regularmente em outras representações por escolas primárias na última década do Império. Este é o caso da petição submetida em 1886 pelos habitantes do bairro de Pederneiras, em Tatuí, na região de Sorocaba. Os moradores pediam uma escola de primeiras letras para o sexo masculino, justificando que residiam a "14 quilômetros mais ou menos" da cidade e que havia "meninos que necessitam de instrução em número não inferior a cinquenta e nove (59)". Os signatários diziam contar com o reconhecimento dos membros da assembleia legislativa de que a "instrução primária (...) é o primeiro passo para o desenvolvimento social". O que chama atenção é que dos 20 pais que subscreveram o abaixo-assinado, nada menos do que 19 (95\%) deles eram analfabetos, tendo de recorrer a terceiros para registrar os seus nomes no documento. ${ }^{78}$

As proporções de analfabetos continuaram variando caso a caso. Em 1886, vinte e dois moradores do bairro Ribeirão Vermelho, na freguesia de Nossa Senhora do Ó, na capital, pleitearam a criação de uma cadeira de primeiras letras para o sexo masculino, sob a justificativa de que no local "existem mais de sessenta meninos analfabetos" e as escolas mais próximas ficavam a mais de duas léguas de distância. Os moradores tomaram a iniciativa de organizar um censo das crianças sem escolas no bairro, anexando-o à petição. Entre os 22 signatários, dezoito (82\%) deles eram analfabetos. ${ }^{79}$ No ano seguinte, os habitantes do bairro Várzea do Socorro, no então município de Santo Amaro, pediram uma cadeira primária para ambos os sexos a fim de atender 42 crianças sem acesso à instrução, de acordo com o levantamento que realizaram no local. Trinta e dois moradores assinaram a petição, sendo cinco (16\%) analfabetos. ${ }^{80}$ Em Sorocaba, uma representação de moradores do bairro de Piragibu reivindicando uma escola feminina foi assinada por 13 pais, dos quais 10 (77\%) analfabetos. ${ }^{81}$ No bairro de Inhaíba, também em Sorocaba, dos 14 signatários com nomes legíveis na petição de 26 moradores, reivindicando uma cadeira de primeiras letras para meninos, havia 13

\footnotetext{
${ }^{78}$ Tatuí, Criação de escola primária, 1886. Fundo Império, Acervo Histórico Alesp, caixa 439, doc. IP 86.52.1.

${ }^{79}$ Capital, Criação de escola primária, 1886. Fundo Império, Acervo Histórico Alesp, caixa 439, doc. IP 86.46.2.

${ }^{80}$ Santo Amaro, Criação de escola primária, 1883. Fundo Império, Acervo Histórico Alesp, caixa 440, doc. IP 87.25.2.

${ }^{81}$ Sorocaba, Criação de escola primária, 1887. Fundo Império, Acervo Histórico Alesp, caixa 603, doc. PR 87.69.1.
} 
(93\%) analfabetos. ${ }^{82}$ Já em vila Bela da Princesa (Ilhabela), dos 20 moradores do bairro de Jabaquara, que no início de 1889 pediam uma escola para 32 meninas, pelo menos nove (45\%) eram incapazes de ler e escrever. ${ }^{83}$ Ou seja, a presença de analfabetos variou entre os autores das petições, mas tal como ocorreu nas décadas anteriores, pais que não haviam recebido educação formal mobilizaram-se para reivindicar escola pública para seus filhos.

Um aspecto adicional a ser analisado na composição dos signatários das petições diz respeito às suas nacionalidades. Há indícios de que a presença de imigrantes pode ter contribuído para impulsionar a demanda por escolas primárias em diversas localidades de São Paulo. ${ }^{84}$ Na maior parte do período aqui analisado, porém, havia relativamente poucos imigrantes europeus entre os pais e moradores que reivindicaram escolas ao legislativo. A situação somente começou a mudar na década de 1870. Como as nacionalidades não aparecem registradas nas petições, os imigrantes podem ser identificados indiretamente pelos sobrenomes nos abaixo-assinados, o que implica incluir no cálculo os estrangeiros de $1^{\mathrm{a}}$ geração e seus descendentes. Uma limitação desse método é que imigrantes portugueses e, muitas vezes espanhóis, deixam de ser classificados pela impossibilidade de distingui-los de nomes brasileiros, concentrando-se a análise nos estrangeiros de imigração mais recente, como alemães, suíços e italianos. Sob esse critério, por exemplo, na freguesia de Dois Córregos, município de Brotas, havia apenas quatro (6\%) imigrantes no total de 63 signatários de uma representação pedindo uma escola primária para meninas em $1869 .{ }^{85}$ De fato, o mais comum até meados da década de 1870 era uma presença marginal ou nula de imigrantes nas representações à assembleia legislativa, com os brasileiros predominando de forma absoluta.

Uma proporção maior de imigrantes aparece na petição já citada dos moradores do Alto da Serra, na estrada da capital para Santos em 1875, onde

\footnotetext{
${ }^{82}$ Sorocaba, Criação de escola primária, 1887. Fundo Império, Acervo Histórico Alesp, caixa 603, doc. PR 87.68.1.

${ }^{85}$ Bela da Princesa, Criação de escola primária, 1889. Fundo Império, Acervo Histórico Alesp, caixa 443, doc. IP 89.3.2.

${ }^{84}$ CARVALHO FILHO, Irineu de $\mathcal{E}$ COLISTETE, Renato P. Education performance: was it all determined 100 years ago? Evidence from São Paulo, Brazil. MPRA Papers, $\mathrm{n}^{\circ}$ 24.494. Munique: University Library of Munich, 2010; SOUZA, Bruno Gabriel Wietzel. The combined effect of institutions, op. cit.; ROCHA, Rudi; FERRAZ, Claudio; SOARES, Rodrigo. Human capital persistence and development. American Economic Journal: Applied Economics. vol. 9, nº 4, Pittsburgh, 2017, p. 105-36.

${ }^{85}$ Dois Córregos, Criação de escola, 1869. Fundo Império, Acervo Histórico Alesp, caixa 434, doc. IP 69.1.5.
} 
cinco (19\%) dos 26 pais eram estrangeiros. ${ }^{86}$ Outro exemplo de um número relativamente elevado de imigrantes para a época encontra-se na solicitação em 1879 de uma escola para o sexo masculino do bairro da Cachoeira, em Amparo. Trinta e cinco pessoas assinaram a petição, dos quais três (9\%) eram imigrantes. ${ }^{87} \mathrm{O}$ número relativo de imigrantes nas petições aumentou nos anos 1880. No caso do bairro da Rua do Porto em Piracicaba citado anteriormente, por exemplo, das 100 assinaturas da petição submetida em 1884, oitenta e oito puderam ter sua nacionalidade identificada, das quais pelo menos 19 (21,6\%) eram nomes de origem alemã, suíça ou italiana. Na capital, sessenta e um moradores do bairro Caguassu organizaram-se em 1882 para reivindicar uma cadeira de primeiras letras para o sexo feminino. Dos 49 nomes em que foi possível identificar a nacionalidade, 11 dos signatários $(22,5 \%)$ eram de origem ou descendência europeia. ${ }^{88}$

Nas colônias oficiais estabelecidas em São Paulo, os colonos estrangeiros tendiam, naturalmente, a aparecer em maior número nas petições. Já em 1888, os agricultores do núcleo colonial de Canas, no município de Lorena, diziam que eles, "colonos Portugueses, Italianos, Belgas e Brasileiros", pediam "encarecidamente" que fosse "estabelecida logo uma escola nesta Colônia, onde possamos dar educação e instrução aos nossos filhos, que atualmente estão crescendo sem saber ler nem escrever, o que é bem triste (...) de ver-se em um centro povoado como estamos". De um total de 43 signatários da petição, vinte e oito (65\%) eram imigrantes. O número de analfabetos também era elevado: dezesseis (37\%) do total, todos eles estrangeiros. ${ }^{89}$

Uma referência explícita ao papel dos imigrantes nas reivindicações por escolas primárias ocorreu em Santa Bárbara, na região central de São Paulo. Tendo em vista "o excessivo número de meninos que existem nesta Vila e seus arrabaldes que vagam pelas ruas e sítios sem a precisa educação escolar" e o grande número de alunos matriculados na única escola pública local, o inspetor literário daquele município pediu em 1886 a abertura de mais

${ }^{86}$ Capital, Criação de escola, 1875. Fundo Império, Acervo Histórico Alesp, caixa 435, doc. IP 75.3.2.

${ }^{87}$ Amparo, Criação de escola, 1879. Fundo Império, Acervo Histórico Alesp, caixa 436, doc. IP 79.1.1.

${ }^{88}$ Capital, Criação de escola primária, 1882. Fundo Império, Acervo Histórico Alesp, caixa 378, doc. CJ 82.41.2.

${ }^{89}$ Lorena, Criação de escola primária, 1888. Fundo Império, Acervo Histórico Alesp, caixa 604, doc. PR 88.30.11. O núcleo colonial de Canas foi estabelecido oficialmente em 1885, com os primeiros colonos estrangeiros chegando em 1887. 
uma escola primária, "atendendo às justas reclamações dos pais de família tanto estrangeiros como nacionais, e sobretudo daqueles (...)".90 A menção às reclamações dos pais estrangeiros, relatadas pelo inspetor como sendo ainda mais frequentes do que as dos nacionais, indica um impulso adicional na demanda por mais escolas com a chegada dos imigrantes na região. Por outro lado, os pais de nacionalidade brasileira também assumiram a iniciativa em localidades sem a presença estrangeira ou frequentemente eram maioria quando havia imigrantes e seus descendentes entre os signatários de representações por mais escolas. Em termos quantitativos, os pais e moradores de nacionalidade brasileira continuaram predominando entre os signatários dos pedidos de escolas primárias públicas nas localidades de São Paulo.

Os dados básicos das petições encaminhadas por pais e moradores são apresentados na tabela 1. Não é possível assegurar que esses números sejam representativos dos pedidos e abaixo-assinados elaborados pelos habitantes do conjunto de municípios da província de São Paulo. Primeiro, porque os dados não incluem eventuais petições que deixaram de ser acolhidas pelas comissões de instrução pública e, portanto, não constam dos anexos dos projetos de lei propondo a criação de escolas primárias. Segundo, há relativamente poucos projetos de lei que são acompanhados por anexos que permitem reconstituir o histórico dos pedidos que subsidiaram a redação das propostas de abertura de escolas. Terceiro, aparentemente a maior parte das manifestações de pais e moradores por escolas ocorria no contato direto com membros das câmaras locais, conforme pode ser constatado nas frequentes referências aos pedidos e reclamações dos pais nas representações dessas câmaras ao legislativo provincial e estadual, algumas das quais foram vistas anteriormente. Da mesma forma que o observado nas representações das câmaras municipais, os dados da tabela 1 abrangem um leque variado de regiões (capital, litoral e interior) e localidades (sedes de municípios, distritos e bairros rurais) da província de São Paulo, o que sugere que as petições não foram limitadas geograficamente ou restritas a núcleos urbanos.

\footnotetext{
${ }^{90}$ Santa Bárbara, Criação de escola primária, 1886. Fundo Império, Acervo Histórico Alesp, caixa 438, doc. IP 86.19.2.
} 
Tabela 1

Petições de pais e moradores por escolas primárias, São Paulo, 1830-1889

\begin{tabular}{|c|c|c|c|c|c|}
\hline Anos & $\begin{array}{c}\mathrm{N}^{0} \text { de } \\
\text { petições }\end{array}$ & $\begin{array}{c}\mathrm{N}^{0} \text { de } \\
\text { signatários }\end{array}$ & Anos & $\begin{array}{c}\mathrm{N}^{\circ} \text { de } \\
\text { petições }\end{array}$ & $\begin{array}{c}\mathrm{N}^{\text {o }} \text { de } \\
\text { signatários }\end{array}$ \\
\hline 1830 & 1 & 21 & 1874 & 2 & 45 \\
\hline 1840 & 1 & 22 & 1875 & 1 & 26 \\
\hline 1843 & 1 & 27 & 1876 & 1 & 21 \\
\hline 1845 & 1 & 83 & 1877 & 2 & 54 \\
\hline 1847 & 1 & 77 & 1878 & 2 & 76 \\
\hline 1849 & 1 & 31 & 1879 & 1 & 35 \\
\hline 1860 & 1 & 22 & 1880 & 1 & 19 \\
\hline 1861 & 1 & 98 & 1882 & 1 & 61 \\
\hline 1863 & 1 & 16 & 1884 & 1 & 100 \\
\hline 1868 & 1 & 34 & 1885 & 1 & 40 \\
\hline 1869 & 1 & 63 & 1886 & 3 & 88 \\
\hline 1871 & 1 & 43 & 1887 & 3 & 72 \\
\hline 1872 & 1 & 13 & 1888 & 2 & 63 \\
\hline 1873 & 2 & 36 & 1889 & 3 & 103 \\
\hline
\end{tabular}

Fonte: Província de São Paulo, Pareceres da Comissão de Instrução Pública e anexos de projetos de lei. Fundo Império, Acervo Histórico Alesp, vários anos.

Nota: as petições listadas incluem apenas aquelas com texto e assinatura dos autores, encontradas em pareceres e anexos de projetos de lei, excluindo, assim, pedidos feitos diretamente às câmaras municipais.

É possível observar mais claramente por meio da figura 1 que os pais e moradores que não sabiam ler e escrever constituíram uma parcela substancial dos que subscreveram petições por escolas primárias no período. Os dados agregados mostram que os analfabetos representaram entre 20 e $60 \%$ dos signatários na maior parte dos anos da série, indicando que a mobilização por escolas primárias não se restringia aos já alfabetizados. Pais que não tiveram acesso a algum tipo de ensino formal consideraram valioso que seus filhos frequentassem as aulas primárias públicas para o aprendizado das primeiras letras. 


\section{Figura 1}

Analfabetos entre signatários de petições por escolas, província de São Paulo, 1830-1889 (em porcentagem)

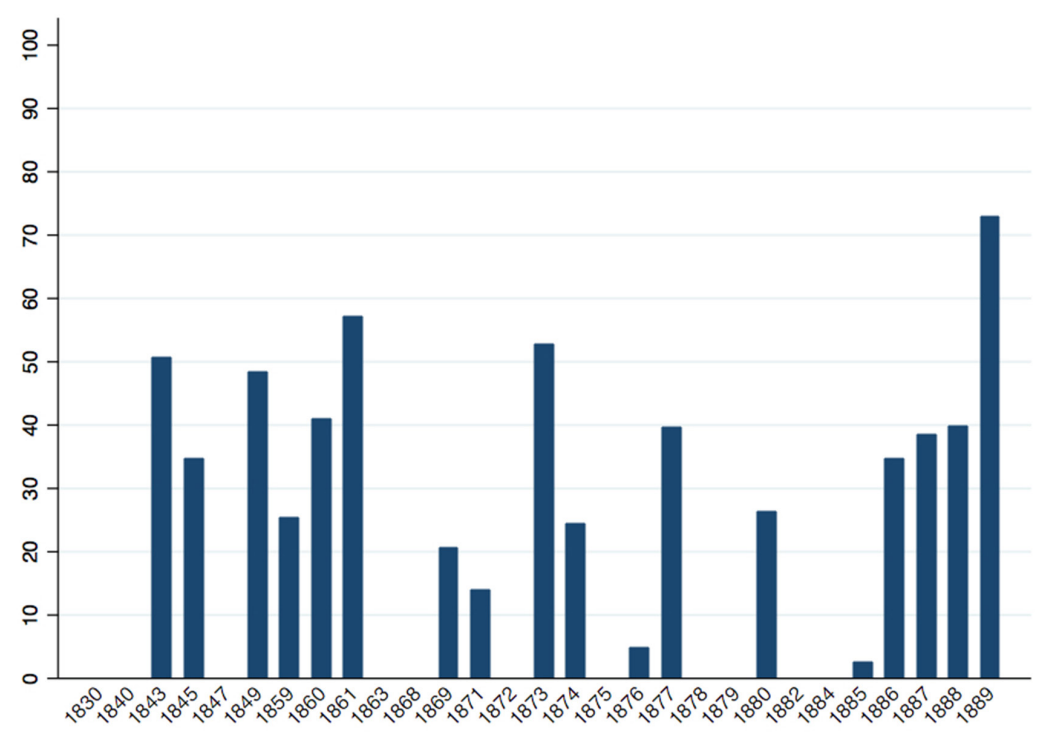

Fontes: Petições de pais e moradores. Fundo Império, Acervo Histórico Alesp.

\section{Figura 2}

Imigrantes entre signatários de petições por escolas, província de São Paulo, 1830-1880 (em porcentagem)

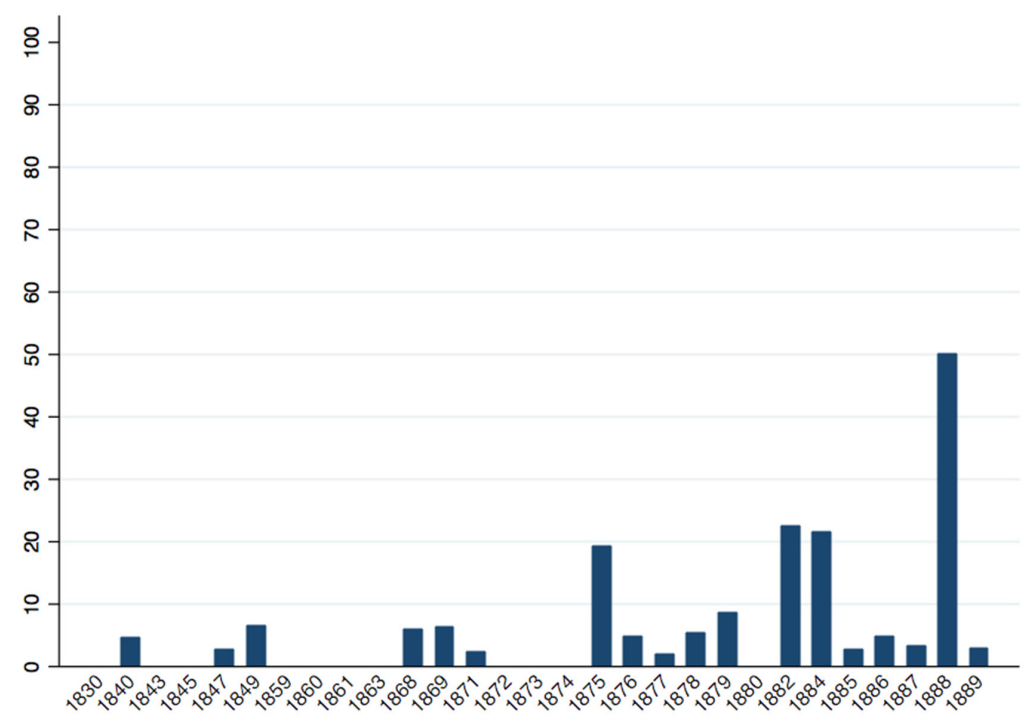

Fontes: Petições de pais e moradores. Fundo Império, Acervo Histórico Alesp. 
Os números de imigrantes também ilustram outra característica mencionada anteriormente. Vê-se na figura 2 que a presença de imigrantes europeus foi marginal entre os autores das petições por escolas públicas primárias entre 1830 e 1870. A partir de 1875 nota-se uma frequência maior de europeus de $1^{\text {a }}$ geração ou descendentes, o que pode ser um reflexo das entradas ainda relativamente pequenas, mas contínuas, de europeus que precederam a grande onda imigratória a partir de 1887 em São Paulo.

\section{Conclusões}

Ao final, o que pode ser depreendido das evidências extraídas das reivindicações por escolas feitas por câmaras, conselhos de instrução e pais e moradores em São Paulo durante o Império? Ainda que a participação das localidades seja um aspecto pouco conhecido do sistema educacional da época, os relatórios e petições indicam que, em várias ocasiões, câmaras, conselhos, pais e moradores mobilizaram-se pela criação de escolas primárias públicas, inclusive aquelas voltadas ao ensino de meninas que, no início do século XIX, tinham uma presença ínfima entre as crianças matriculadas. Essa participação local foi limitada e intermitente, acomodando-se, muitas vezes, ao baixo número de vagas nas escolas públicas e às condições precárias com que o ensino era oferecido. Outros assuntos dominaram a atenção das câmaras, como a situação de estradas, cemitérios, cadeias ou das igrejas matrizes, que faziam parte do amplo espectro de atribuições municipais definidas pelas leis gerais ou por tradição. Apesar dessas limitações, as evidências citadas anteriormente indicam que representantes das câmaras, membros dos conselhos municipais e pais e moradores exerceram um papel que não foi desprezível nas demandas para criação e ampliação das escolas primárias públicas.

O que tornava ainda mais incerta a mobilização pelo ensino primário eram as regras do regime constitucional que subordinava o município à província. Representantes e moradores de cidades, vilas e freguesias dirigiam seus pedidos ao governo e ao legislativo provinciais utilizando expedientes e aliados com os quais pudessem contar. O crucial, no entanto, era que as decisões e os recursos públicos permaneciam nas mãos da assembleia legislativa, constrangidos por interesses e prioridades definidos pelos deputados e pelo poder executivo provincial. A dependência frente à assembleia legislativa e ao seu poder de criar ou não escolas tendia a inibir e desestimular as iniciativas locais. Da mesma maneira, por ser a nomeação de professores e a administração das escolas públicas locais de competência exclusiva da província, havia poucos incentivos para que as câmaras ou as 
famílias dos alunos se envolvessem com os assuntos do ensino elementar. A mudança desse quadro exigiria a subversão da tutela exercida pelo governo e pelo legislativo provinciais sobre a instrução pública, o que dificilmente as câmaras locais tinham força ou interesse em fazer.

Outro motivo para a limitação do envolvimento da população local com a instrução pública foi apontado em vários relatos da época. Os habitantes de maior riqueza, fazendeiros ou não, garantiam que seus filhos estudassem em escolas privadas ou por meio de tutorias particulares, não dependendo dos estabelecimentos públicos de ensino. As escolas públicas serviam especialmente à grande maioria dos habitantes que possuíam poucos recursos e eram muitas vezes eles mesmos analfabetos. Nessa população havia lavradores, pequenos comerciantes, artesãos, empregados e funcionários públicos. Era essa população, ou seu representante nas câmaras, que teria de se organizar para conseguir subsídios da província para a educação de seus filhos.

Em conjunto, pobreza, analfabetismo e centralização impunham um alto custo à ação coletiva de pais e moradores sem acesso a escolas primárias. Tal fato dá um significado especial às evidências de atuação de pais, moradores e representantes das câmaras, que se mobilizaram em condições especialmente adversas a fim de obter recursos e vagas para o ensino primário em São Paulo no século XIX. Da mesma forma, essas evidências são indícios que conflitam com as visões que, no século XIX e posteriormente, consideraram inconsequente a participação direta da população nos negócios públicos e advogaram a inviabilidade das instituições democráticas do autogoverno local.

\section{Referências bibliográficas}

ALVES, Silvane R. L. A instrução pública em Indaiatuba: 1854-1930. Contribuição para a história da educação brasileira. Dissertação de mestrado em Educação, Faculdade de Educação, Universidade Estadual de Campinas, 2007.

BARROS, Surya A. P. de. "Negrinhos que por ahí andão": a escolarização da população negra em São Paulo (1870-1920). Dissertação de mestrado em Educação, Faculdade de Educação, Universidade de São Paulo, 2005.

BASTOS, Aureliano Cândido Tavares. A Provincia. Estudo sobre a descentralisação no Brazil. Rio de Janeiro: B. L. Garnier, 1870.

BEZERRA, Maria Cristina S. Imigração, educação e religião: um estudo histórico-sociológico do bairro dos Pires de Limeira, uma comunidade rural de maioria teuto-brasileira. Dissertação de mestrado em Educação, Faculdade de Educação, Universidade Estadual de Campinas, 2001.

Educação étnica: a pluralidade das propostas educacionais de origem germânica no Estado de São Paulo. Tese de doutorado em Educação, Faculdade de Educação, Universidade Estadual de Campinas, 2007. 
BRASIL. Ministério da Justiça. Relatorio da Repartição dos Negocios da Justiça apresentado á Assembléa Geral Legislativa na sessão ordinaria de 1841, pelo respectivo Ministro e Secretario de Estado, Paulino José Soares de Sousa. Rio de Janeiro: Typographia Nacional, 1841.

Collecção das leis do Imperio do Brazil - 1834, parte I. Rio de Janeiro: Typographia Nacional, 1866.

Collecção das leis do Imperio do Brazil - 1827, parte I. Rio de Janeiro: Typographia Nacional, 1878a.

Collecção das leis do Imperio do Brazil - 1828, parte I. Rio de Janeiro: Typographia Nacional, 1878b.

Recenseamento da população do Império do Brasil de 1872, vol. I. Rio de Janeiro: Typ. de Leuzinger e Filhos, 1876.

CAMPOS, Maria M. Malta. Escola e participação popular: a luta por educação elementar em dois bairros de São Paulo. Tese de doutorado em Ciências Sociais, Faculdade de Filosofia, Letras e Ciências Humanas, Universidade de São Paulo, 1982.

CARVALHO FILHO, Irineu de $\mathcal{E}$ COLISTETE, Renato P. Education performance: was it all determined 100 years ago? Evidence from São Paulo, Brazil. MPRA Papers, $n^{0}$ 24.494. Munique: University Library of Munich, 2010.

COLISTETE, Renato Perim. O atraso em meio à riqueza: uma história econômica da educação primária em São Paulo, 1835 a 1920. Tese de livre-docência, Faculdade de Economia, Administração e Contabilidade, Universidade de São Paulo, 2016.

COSTA, Ana Luiza Jesus da. O educar-se das classes populares oitocentistas no Rio de Janeiro entre a escolarização e a experiência. Tese de doutorado em Educação, Faculdade de Educação, Universidade de São Paulo, 2012.

CRUZ, Marileia dos Santos. A educação dos negros na sociedade escravista do Maranhão provincial. Outros Tempos, vol. 6, nº 8, São Luís, 2009, p. 110-29.

FERREIRA, Salete Beatriz Braga Xavier. A expansão escolar campineira e a grande lavoura no fim do Império (1860-1889). Dissertação de mestrado em Educação, Faculdade de Educação, Universidade Estadual de Campinas, 1982.

FONSECA, Marcos Vinícius. Pretos, pardos, crioulos e cabras nas escolas mineiras do século XIX. Tese de doutorado em Educação, Faculdade de Educação, Universidade de São Paulo, 2007.

FLORY, Thomas. Judge and jury in imperial Brazil, 1808-1871. Social control and political stability in the new state. Austin: University of Texas Press, 1981.

GRININGER, Valdemar. Imigração suíça em São Paulo: a história da colônia Helvetia. Dissertação de mestrado em História, Instituto de Filosofia e Ciências Humanas, Universidade Estadual de Campinas, 1991.

HILSDORF, Maria Lucia Spedo. Francisco Rangel Pestana: o educador esquecido. Brasília: Instituto Nacional de Estudos e Pesquisas Educacionais, 1998.

JAMES, Herman G. The constitutional system of Brazil. Washington: Carnegie Institution, 1923.

LAXE, João Baptista Cortines. Regimento das camaras municipaes. $2^{\mathrm{a}}$ edição. Rio de Janeiro: B. L. Garnier, 1885.

LEAL, Aurelino. Historia constitucional do Brazil. Rio de Janeiro: Imprensa Nacional, 1915. 
LEAL, Victor Nunes. Coronelismo, enxada e voto. $O$ município e o regime representativo no Brasil. 2a edição. São Paulo: Alfa-Omega, 1979 [1949].

MAIA, João de Azevedo Carneiro. O municipio. Estudos sobre administração local. Rio de Janeiro: Typ. de Leuzinger $\&$ Filhos, 1883.

MARCÍLIO, Maria Luiza. História da escola em São Paulo e no Brasil. São Paulo: Imprensa Oficial do Estado de São Paulo e Instituto Fernand Braudel, 2005.

MORAES, Carmen S. Vidigal. O ideário republicano e a educação: o ensino em Campinas no final do século XIX. Revista da Faculdade de Educação, vol. 11, n 1-2, São Paulo, 1985, p. 101-34.

NAGLE, Jorge. Educação e sociedade na Primeira República. São Paulo: Editora Pedagógica e Universitária, 1974.

RIBEIRO, Luaê Carregari Carneiro. Uma América em São Paulo: a maçonaria e o Partido Republicano Paulista (1868-1889). Dissertação de mestrado em História, Faculdade de Filosofia, Letras e Ciências Humanas, Universidade de São Paulo, 2011.

ROCHA, Rudi; FERRAZ, Claudio; SOARES, Rodrigo. Human capital persistence and development. American Economic Journal: Applied Economics. vol. 9, nº 4, Pittsburgh, 2017, p. 105-36.

SCHUELER, Alessandra F. Martinez de. Crianças e escolas na passagem do Império para a República. Revista Brasileira de História, vol. 19, nº 37, São Paulo, 1999, p. 59-84. doi:http://dx.doi.org/10.1590/S0102-01881999000100004.

SILVA, Noemi Santos da. O "batismo da instrução": projetos e práticas de instrução formal de escravos, libertos e ingênuos no Paraná provincial. Dissertação de mestrado em História, Setor de Ciências Humanas, Letras e Artes, Universidade Federal do Paraná, 2014.

SOUZA, Bruno Gabriel Wietzel de. The combined effect of institutions and human capital for economic development: a case study of German immigration to São Paulo, Brazil, 18401920. Master dissertation in Development Economics, Chair of Development Economics, Georg-August-Universität Göttingen, 2014.

SPOSITO, Marília Pontes. O povo vai à escola: a luta popular pela expansão do ensino público em São Paulo. São Paulo: Loyola, 1984.

VIANA, Francisco José de Oliveira. Pequenos estudos de psicologia social. $3^{\text {a }}$ edição. São Paulo: Cia. Editora Nacional, 1942 [1921]. . Instituições políticas brasileiras. Brasília: Senado Federal, 1999 [1949].

Visconde do Uruguay. Ensaio sobre o direito administrativo. Rio de Janeiro: Typographia Nacional, 1862. 